University of Nebraska - Lincoln

DigitalCommons@University of Nebraska - Lincoln

\title{
Male Brown-headed Cowbird Attacks and Kills a Nestling
}

Lawrence D. Igl

USGS Northern Prairie Wildlife Research Center, ligl@usgs.gov

Follow this and additional works at: https://digitalcommons.unl.edu/usgsnpwrc

Part of the Other International and Area Studies Commons

Igl, Lawrence D., "Male Brown-headed Cowbird Attacks and Kills a Nestling" (2003). USGS Northern Prairie Wildlife Research Center. 188.

https://digitalcommons.unl.edu/usgsnpwrc/188

This Article is brought to you for free and open access by the US Geological Survey at DigitalCommons@University of Nebraska - Lincoln. It has been accepted for inclusion in USGS Northern Prairie Wildlife Research Center by an authorized administrator of DigitalCommons@University of Nebraska - Lincoln. 
Wilson Bull., 115(2), 2003, pp. 210-212

\title{
Male Brown-headed Cowbird Attacks and Kills a Nestling
}

\author{
Lawrence D. Igl'
}

\begin{abstract}
I observed a male Brown-headed Cowbird (Molothrus ater) attack and kill a nestling of an unidentified passerine in a grassland field in Day County, South Dakota, in June 2000. The killing or removal of nestlings by female cowbirds has been reported by others, but this behavior has not been documented previously in male cowbirds. Received $8 \mathrm{Oc}$ tober 2002, accepted 3 March 2003.
\end{abstract}

Female Brown-headed Cowbirds (Molothrus ater) often remove and sometimes eat host eggs (e.g., Scott et al. 1992). Female cowbirds have been observed attacking, removing, or killing nestlings (Du Bois 1956, Tate 1967, Beane and Alford 1990, Scott and McKinney 1994, Sheppard 1996), and recent technological advances in videography have provided evidence that this behavior may be more common than previously believed (Averill-Murray et al. 1999, Elliott 1999, Thompson et al. 1999, Pietz and Granfors 2000, Granfors et al. 2001, Stake and Cavanagh 2001). In some cases, female cowbirds have been observed destroying or removing entire host clutches or broods (e.g., Beane and Alford 1990, Scott and McKinney 1994, Elliott 1999, Granfors et al. 2001, Stake and Cavanagh 2001, pers. obs.).

Observations of male cowbirds exhibiting interest in nests or nest contents are uncommon (Sealy 1994), although males occasion-

' USGS Northern Prairie Wildlife Research Center, 8711 37th St. SE, Jamestown, ND 58401-7317, USA; e-mail: larry_igl@usgs.gov ally are observed in the vicinity of nests with females (Du Bois 1956, Mengel and Jenkinson 1970, Strausberger 1998). Friedmann (1963) described two male and three female cowbirds destroying a Chipping Sparrow (Spizella passerina) nest several days after two cowbird eggs had disappeared from the nest ("mafia effect"; Soler et al. 1995). Sealy (1994) reported one instance of a male cowbird removing an egg from an Eastern Kingbird (Tyrannus tyrannus) nest. E. Greene (pers. comm.) videotaped male cowbirds removing and consuming eggs from both artificial nests and Lazuli Bunting (Passerina amoena) nests in Montana. Despite these reports, male cowbirds have not previously been observed removing or killing nestlings. Here, I report my observations of a male cowbird attacking and killing a nestling in northeastern South Dakota.

On 16 June 2000 at 05:23 CST, while conducting a breeding bird survey in an idle Conservation Reserve Program grassland field $\left(97^{\circ} 45^{\prime} \mathrm{N}, 45^{\circ} 19^{\prime} \mathrm{W}\right)$ in Day County, South Dakota, I observed a female and a male Brown-headed Cowbird flying about $0.5 \mathrm{~m}$ above the vegetation. The male cowbird was carrying a nestling of an unknown passerine species grasped by the neck in his bill. The nestling was flailing its legs, wings, and head, and opening its bill. A male Red-winged Blackbird (Agelaius phoeniceus) briefly pursued the cowbirds as they flew over the blackbird's song perch. The male cowbird alighted 
on a wooden fencepost at the edge of the field (about $25 \mathrm{~m}$ from my observation point) and dropped the still active nestling onto the fencepost; the female cowbird landed on a barbed wire strand near the male. While holding the nestling down with its right foot, the male cowbird repeatedly pecked the nestling's head until the nestling was motionless and bloody. The male cowbird then flew off with the limp nestling in its bill and dropped it in a nearby pasture, about $100 \mathrm{~m}$ from the fencepost. The female cowbird departed with the male cowbird. Although my presence may have influenced the cowbird's behavior, there was no indication that the male intended to consume the nestling. Upon searching the pasture, I was unable to locate the discarded nestling in the dense vegetation.

The species of nestling was not obvious, but it appeared to be that of a larger passerine (cowbird-sized or larger), based on its size and age (i.e., recently hatched, largely naked, sparse light gray down on head, eyes closed). Several passerine species were recorded during the breeding bird survey in the vicinity of the observation, including Red-winged Blackbird, Western Meadowlark (Sturnella neglecta), and Bobolink (Dolichonyx oryzivorus). About $33 \%$ of passerine nests $(n=143)$ found incidentally during bird surveys in grassland fields in this county between 1990 and 2002 were parasitized by cowbirds (unpubl. data).

Although I did not observe the male cowbird at a nest, the fact that the nestling was very young and still alive at the beginning of my observation suggests that it was removed from a nest recently by the male cowbird or possibly by a female cowbird. There is increasing evidence that female cowbirds may destroy or remove the contents of nests that they do not intend to parasitize (Arcese et al. 1996, Granfors et al. 2001), but the motivation of such predatory behavior in cowbirds remains speculative. A number of researchers have suggested that consumption of nestlings is not the primary reason for cowbirds removing nestlings from a nest (Scott et al. 1992, Sealy 1994, Ortega 1998, Granfors et al. 2001). Arcese and coworkers (1992, 1996) speculated that cowbirds will destroy nest contents late in the nesting cycle to induce hosts to renest, thus enabling the cowbird to synchronize their egg laying with that of the renesting host. Cowbirds also may disrupt nests in the vicinity of their hosts' nests to reduce competition for the cowbird nestling's food (Granfors et al. 2001) or to reduce competition among conspecifics (Laskey 1950).

Elliott (1999) suggested that infanticide rather than predation may be a more appropriate term to characterize the cowbird's behavior of removing nestlings from nests, because cowbirds do not eat the nestlings and because cowbird fecundity may be enhanced by increased breeding opportunities from the renesting hosts. Regardless of the intent of this male's behavior or the terminology used to describe it, the killing or removal of nestlings appears to be rare among male cowbirds.

\section{ACKNOWLEDGMENTS}

I thank J. E. Austin, P. F. Elliott, D. H. Johnson, D. A. Granfors, P. J. Pietz, and F. R. Thompson for providing constructive comments on earlier drafts of this manuscript. I am grateful to E. Greene, Univ. of Montana, Missoula, for providing information on egg removal and consumption by male cowbirds at artificial and natural nests in Montana. A. Cox (deceased) provided access to her property between 1990 and 2000 .

\section{LITERATURE CITED}

Arcese, P., J. N. M. Smith, AND M. I. Hatch. 1996. Nest predation by cowbirds and its consequences for passerine demography. Proc. Natl. Acad. Sci. 93:4608-4611.

Arcese, P., J. N. M. Smith, W. M. HochachKa, C. M. ROGERS, AND D. LUDWIG. 1992. Stability, regulation, and the determination of abundance in an insular Song Sparrow population. Ecology 73: 805-882.

AVerill-Murray, A., S. LynN, AND M. L. Morrison. 1999. Cowbird parasitism of Arizona Bell's Vireos (Vireo bellii arizonae) in a desert riparian landscape: implications for cowbird management and riparian restoration. Stud. Avian Biol. 18: 109-120.

Beane, J. C. And S. L. Alford. 1990. Destruction of a Pine Warbler brood by an adult cowbird. Chat 54:85-87.

Du Bols, A. D. 1956. A cowbird incident. Auk 73: 286.

ElLioT, P. F. 1999. Killing of host nestlings by the Brown-headed Cowbird. J. Field Ornithol. 70:5557.

FriedmanN, H. 1963. Host relations of the parasitic cowbird. U.S. Natl. Mus. Bull. 233:1-276.

Granfors, D. A., P. J. Pietz, and L. A. Joyal. 2001. Frequency of egg and nestling destruction by female Brown-headed Cowbirds in grassland nests. Auk 118:765-769. 
Laskey, A. R. 1950. Cowbird behavior. Wilson Bull. 62:157-174.

Mengel, R. M. And M. A. Jenkinson. 1970. Parasitism by the Brown-headed Cowbird on a Brown Thrasher and a catbird. Wilson Bull. 82:74-78.

OrtegA, C. P. 1998. Cowbirds and other brood parasites. Univ. of Arizona Press, Tucson.

Pietz, P. J. AND D. A. Granfors. 2000. Identifying predators and fates of grassland passerine nests using miniature video cameras. J. Wildl. Manage. 64:71-87.

Scott, D. M., P. J. Weatherhead, And C. D. Ankney. 1992. Egg-eating by female Brown-headed Cowbirds. Condor 94:579-584.

SCOTT, P. E. AND B. R. MCKINNEY. 1994. Brown-headed Cowbird removes Blue-gray Gnatcatcher nestlings. J. Field Ornithol. 65:363-364.

SEALY, S. G. 1994. Observed acts of egg destruction, egg removal, and predation on nests of passerine birds at Delta Marsh, Manitoba. Can. Field-Nat. 108:41-51.

ShePpard, J. M. 1996. Nestling Kentucky Warblers and cowbird attacked by Brown-headed Cowbird. J. Field Ornithol. 67:384-386.

Soler, M., J. J. Soler, J. G. Martinez, and A. P. MøLLER. 1995. Host manipulation by the Great Spotted Cuckoos: evidence for an avian mafia? Evolution 49:770-775.

Stake, M. M. and P. M. Cavanagh. 2001. Removal of host nestlings and fecal sacs by Brown-headed Cowbirds. Wilson Bull. 113:456-459.

STRAuSBerger, B. M. 1998. Evident nest-searching behavior of female Brown-headed Cowbirds while attended by males. Wilson Bull. 110:133-136.

TATE, J., JR. 1967. Cowbird removes warbler nestling from nest. Auk 84:422.

Thompson, F. R., III, W. DiJAK, and D. E. Burhans. 1999. Video identification of predators at songbird nests in old fields. Auk 116:259-264. 